\title{
1. Introduction: context and importance of patent information for development
}

A patent is a legal document that confers a set of exclusive rights for the use and exploitation of an invention in exchange for its public disclosure. ${ }^{1}$ These rights are issued by a governing authority to grant particular privileges and specific rights to their holders. Hence, patents might be perceived as an impediment to development since they are intended to prevent others from using technologies encompassed in patent documents. ${ }^{2}$ Focusing too much on those exclusive rights, the literature has quite often overlooked other aspects of patents. Indeed, though historically patents used to be issued under governmental seal, patents are, in essence, open to public inspection. In this respect patents were termed 'litterae patentes' ${ }^{3}$ Patents are 'open letters'; they are 'open to view'. ${ }^{4}$ Originating from the Latin patens, the quintessence of patents resides in spreading open, expanding, opening to public inspection, or simply opening to the general public. This book focuses on the 'open' function of the patent that is achieved through the disclosure of patent information. ${ }^{5}$ The teaching or utilitarian function of patents is enhanced by the fact that patents are territory-limited and are also restricted in time

\footnotetext{
1 M Lupu, K Mayer, J Tait and A J Trippe (eds), Current Challenges in Patent Information Retrieval (Springer 2011) 88.

2 On this subject, see Adam B Jaffe and Josh Lemer, Innovation and Its Discontents: How Our Broken Patent System is Endangering Innovation and Progress, and What to do About It (Princeton University Press 2004) 14-19.

3 See Black's Law Dictionary (8th edn, West 2004) 'Letters patent'.

4 In the online Etymology Dictionary, patent is an 'open letter or document from authority'. Shortened form of Anglo-French 'lettre patent' (Medieval Latin 'litterae patentes').

5 Bingbin Lu, 'Disclosure Requirements for Patent Application: Article 29 of the TRIPS Agreement and a Dimensional Exploration' (2012) 34 European Intellectual Property Review 336. Sean B Seymore, 'The Teaching Function of Patents' (2010) 85 Notre Dame Law Review 621.
} 
and in scope. ${ }^{6}$ Today, due to the evolution from the industrial age to the information age, the disclosed patent information is becoming an ever more crucial force behind the competitiveness of industrial organisations. $^{7}$ The commercial value of patent information is increasing, global economic competition is perpetually growing, and it is more and more based on technological leadership. ${ }^{8}$

Patent information can be used for various purposes. To start with, it can be used to determine the prevailing technical knowledge in a particular subject area. The purpose of this use is to gain a comprehensive overview of a product or a technology. It is called the 'state-of-theart search'. ${ }^{9}$ For instance, people interested in technical or competitive intelligence frequently refer to patent information as 'landscaping studies'. Typically, patent information is used to identify shifts in technology over time and interest in technology sub-categories. It is not uncommon for researchers and businesses to search for prior art, and when entering a new technical area to have a thorough understanding of what the current knowledge is in that particular technical area of interest. This kind of research is usually conducted at the commencement of a research project, before any investment is made, to determine if an innovation is worth pursuing. ${ }^{10}$

Additionally, patent practitioners, particularly patent examiners, commonly use patent information when determining whether an invention is eligible for patent protection, and how broadly the claims for a new invention can be drafted. While searching patent information, patent

6 Paris Convention for the Protection of Industrial Property 1883, art 4bis(1): 'Patents applied for in the various countries of the Union by nationals of countries of the Union shall be independent of patents obtained for the same invention in other countries'; see also TRIPS, arts 28-33.

7 Edith Penrose, The Economics of the International Patent System (Johns Hopkins Press 1951) 137-8: 'The theory that all patents should be worked within the country that granted them arose when the encouragement of industrialization was the chief aim of the patent system ... The question was not one of "rights of inventors" but of industrial development'; also see R Bohn, 'Measuring and Managing Technological Knowledge' (1994) 36(1) MIT Sloan Management Review 61-73.

8 The idea that the real wealth of a country lies in its technological knowledge prevails, for example, in the writings of Jacob Schmookler, 'Technological Change and Economic Theory' (1965) 55 American Economic Review 333-41; see also Keith Maskus, Intellectual Property Rights in the Global Economy (Institute for International Economics 2000) 15-169.

9 Lupu and others (n 1 above) 10.

10 Lupu and others (n 1 above) 127. 
examiners are looking for references that were published before the filing date of the application. Though it is commonly known that this kind of practice is exercised by patent examiners, it is also important for patent applicants to refer to this technical knowledge, mainly for the reasons detailed below. Patent applicants are supposed to disclose the relevant prior art related to their invention. ${ }^{11}$ Subsequently, knowing the existing technical knowledge helps in defining the scope of the technology and the boundaries of the claimed invention. ${ }^{12}$ The result of such search may change the scope of the claims or, if required, lead to a 'draft around' as the coverage is expected to include 'everything made available to the public, in writing, by public use, or otherwise'.13 Apart from that, companies may initiate validity challenges for a granted patent, especially if they consider acquiring or using it in some types of litigation. This case can be associated with large amounts of money and with critical business decisions at stake. This is why due diligence needs to be performed in order to justify the transaction. The recourse to patent information, in this case, shares similar characteristics to use for assessing patentability conditions. The purpose of this search is to identify prior art references to invalidate a granted patent during a re-examination process before the particular patent office or during a court proceeding. ${ }^{14}$

Ultimately, a very particular use of patent information is related to a patent clearance report that is sought when innovators wish to develop new products or services, or make changes to existing products or services, in an attempt to ensure that those products and services will not be open to a claim of patent infringement. Assuming that the product is a new drug, the patent information research needs to identify if any similar component is subject to a patent that is in force in the country where the new product will be brought to the market. ${ }^{15}$ Efficient utilisation of patent information requires that the company applies for a legal opinion

11 On this subject, see Corinne Langinier and Philippe Marcoul, 'Search of Prior Art and Revelation of Information by Patent Applicants' (SSRN 2008) http://ssrn.com/abstract=991172, accessed 14 January 2016.

12 Lupu and others (n 1 above) 128.

13 Lupu and others (n 1 above) 12.

14 Lupu and others (n 1 above) 128.

15 This type of research is country specific, meaning that local patent offices should be consulted to confirm the status of the patent. Additionally, it is prudent to pay close attention to the claims as they may change from one country to another. Equally, it is best not to limit the search to patents related to the product itself, but also to look at the processes needed to manufacture it. This would also include everything from raw materials to packing designs; Lupu and others (n 1 above) 128-9. 
reasonably early in the production cycle, and follows up this opinion to make sure that the situation does not change as they get closer to the commercialisation phase, to avoid intellectual property infringements and related lawsuits.

\subsection{THE DISCLOSURE REQUIREMENT AND THE USE OF PATENT INFORMATION FOR DEVELOPMENT}

The disclosure requirement as set out in article 29 of the Agreement on Trade-Related Aspects of Intellectual Property Rights (TRIPS), and the obligation to publish the disclosed patent information as stated by article 12 of the Paris Convention, are meant to disseminate patent information and, therefore, facilitate its exploitation. ${ }^{16}$ Moreover, because patents describe inventions 'as deeds describe pieces of land' and, since the practical purpose of disclosing a patent specification is to generate legal certainty by defining the boundaries of the claimed invention, dissemination of patent information seeks also to inform third parties that those boundaries should not be trespassed upon. ${ }^{17}$

This book discusses the problem of utilising patent information starting from its disclosure until its utilisation, passing through issues related to availability and accessibility of such information. ${ }^{18}$ It points out that

16 Paris Convention for the Protection of Industrial Property 1883, art 12: 'Each country of the Union undertakes to establish a special industrial property service and a central office for the communication to the public of patents ... This service shall publish an official periodical journal. It shall publish regularly: (a) the names of the proprietors of patents granted, with a brief designation of the inventions patented; (b) the reproductions of registered trademarks.' See Brenner $v$ Manson, 383 US 519 (1966), where this assertion has been challenged by the US Supreme Court. In this ruling the Court has acknowledged the limited value of patents in the dissemination of technical knowledge: 'It is true, of course, that one of the purposes of the patent system is to encourage dissemination concerning discoveries and inventions ... However, in light of the highly developed art of drafting patent claims so that they disclose as little useful information as possible - while broadening the scope of the claim as widely as possible - the argument based upon the virtue of disclosure must be warily evaluated.'

17 Nuno Pires de Carvalho, The TRIPS Regime of Patent Rights (3rd edn, Kluwer Law International 2010) 7.16. Dissemination means 'scatter or spread widely'. See Webster's College Dictionary (Random House 1991).

18 For the purposes of this book, technology transfer assumes that the recipient or simply the user of patent information learns about the disclosed technology and adopts it in a manner enabling him to reproduce it. Adoption and 
though significant technological resources described in patent documents can be freely exploited, these latter remain underutilised. In this respect, authors have considered that 'transfers of technical information' can occur through various channels. ${ }^{19}$ Hence, trade in goods and services involves 'transmitting technological information'.20 Notably, multinational companies 'transfer technological information' to their subsidiaries, which positively impacts the local economy. ${ }^{21}$ More commonly, patent information is directly transferred through trade in knowledge via technology licensing of patents, trademarks or other intellectual property assets. These are perceived as 'facilitators' of knowledge transfers. ${ }^{22}$ This book focuses only on the transfer of technologies which are freely available in the public domain. ${ }^{23}$ Its primary aim is to examine the adequacy of the disclosure requirement in so far as the quality of information received enables developing countries to utilise patent information for development. ${ }^{24}$

In so doing, the central argument of the book is that while article 29 of TRIPS obliges the patentee to make a clear and complete disclosure of the invention, in practice patent information users - particularly those in developing countries - may lack the capacity to access, retrieve and exploit such information for economic development. Since the disclosure requirement is not necessarily adequate to allow optimal exploitation of such information, it is further argued that a right of access to patent information should be made explicit in law rather than implicit. The work critically analyses disclosure as a means of promoting the exploitation of

adaptation of technologies is, therefore, much more complex than purely receiving information. It implies a real partnership between the recipient and the supplier of the technology. See Pires de Carvalho (n 17 above) 7.16.

19 Bernard M Hoekman, Keith E Maskus and Kamal Saggi, 'Transfer of Technology to Developing Countries: Unilateral and Multilateral Policy Options' (2004) Institute of Behavioral Science, University of Colorado at Boulder, Working Paper PEC2004-0003, 9, www.colorado.edu/IBS/pubs/pec/pec20040003.pdf, accessed 14 January 2016.

20 Hoekman, Maskus and Saggi (n 19 above) 3.

21 Hoekman, Maskus and Saggi (n 19 above) 3.

22 Hoekman, Maskus and Saggi (n 19 above) 3.

23 In his book, Legal Aspects of the Transfer of Technology to Developing Countries (ESC 1989) 81-6, Professor Blakeney explains how patent documents can be viewed as a source of technological information and analyses the role of patent information in the transfer of technology.

24 Nefissa Chakroun, 'Improving Patent Information Quality: Development and the Disclosure Requirement' (2012) 15 The Journal of World Intellectual Property 199-220. 
patent information for development. ${ }^{25}$ It takes the approach of utilising patent information as a means of transfer of technology for cumulative research and development.

\subsection{HOW TECHNOLOGY TRANSFER TO DEVELOPING COUNTRIES HAS BEEN ADDRESSED SO FAR?}

To date, the debate related to the transfer of technology to developing countries has mostly focused on providing those countries with the flexibility to benefit from technologies generated by the developed world. ${ }^{26}$ In this respect, in a recent work on how TRIPS is affecting technology transfer to developing and least developed countries, Prabhat Kumar Saha argues that only one aspect of TRIPS has been successfully pursued so far: the protection of technology assets. The other objectives, particularly those related to the transfer and dissemination of technology, are relegated to a secondary position. ${ }^{27} \mathrm{Tu}$ Thanh Nguyen addresses the issue of technology transfer to developing countries from a competition law perspective. On that basis, the author argues that international

25 Jaye Ellis, 'Sustainable Development as a Legal Principle: A Rhetorical Analysis' (SSRN, 22 December 2008) http://papers.ssrn.com/sol3/papers. cfm?abstract_id=1319360, accessed 14 January 2016. On the importance of empirical research, see Bill Marr and Emmy Misser, 'Economic Research Methodology: Writing Tutors, Critical Thinking, and Empirical, Economic Research' (SSRN, 16 May 2007) http://ssrn.com/abstract=987848, accessed 14 January 2016.

26 See Pires de Carvalho (n 17 above) 'Article 66, Least Developed Country Members'; Bernard Hoekman, Global Integrating and Technology Transfer (World Bank 2006); David Silverstein, Patent Protection and Technology Transfer in Less Developed Countries: A Reappraisal of the Legal Framework for Producing and Transmitting Knowledge (Tufts University 1978); Sanjaya Lall, 'Major Issues in Transfer of Technology to Developing Countries: A Case Study of the Pharmaceutical Industry' (UNCTAD 1975); Charles Chukwuma Okolie, Legal Aspects of the International Transfer of Technology to Developing Countries (Praeger 1975); Walter A Chudson, The International Transfer of Commercial Technology to Developing Countries (United Nations Institute for Training and Research 1971); Robert B Stobaugh, The International Transfer of Technology in the Establishment of the Petrochemical Industry in Developing Countries (United Nations Institute for Training and Research 1971); Daniel L Spencer, Transfer of Technology to Developing Countries (Praeger 1968).

27 Prabhat Kumar Saha, TRIPS and Technology Transfer: Developing and Least-Developed Countries' Perspective (VDM Verlag Dr Müller 2011). On the 
technology transfer-related competition law ought to be appropriately 'glocalised' for the needs of local contexts, while intellectual property rights (IPRs) remain 'globalised'. He suggests that TRIPS allows developing countries to use their domestic competition laws to enhance access to technologies. Similarly, they are allowed reasonably to apply and adapt decisions and court judgments issued by developed countries' jurisdictions to their particular circumstances. ${ }^{28}$ Additionally, transfer of technology has been dealt with through the use of compulsory licences. In recent publications, authors are questioning the appropriateness of these licences for the transfer of technologies. ${ }^{29}$ They question their reliability in improving access to technical knowledge and urge developing countries to rely on other mechanisms such as voluntary licences and direct government purchases, especially in the case of patented drugs. That was not the view taken in a recent publication, where authors argued that compulsory licensing related to essential AIDS drugs, to address the rising death and morbidity rates of HIV/AIDS in various developing countries - notably African countries and South East Asia - is preferable, both morally and pragmatically, to other alternatives, such as offered price cuts and drug donation schemes. ${ }^{30}$ Another paper contends that bilateral and regional agreements regulating foreign direct investment that encompass intellectual protection rules, known as 'TRIPS-plus', might have the effect of further limiting the use of compulsory licensing

same subject, see also International Centre for Trade and Sustainable Development (ICTSD), 'Meaningful Technology Transfer to the Least Developed Countries: A Proposal for a Monitoring Mechanism for TRIPS Article 66.2' ICTSD Programme on Innovation, Technology and Intellectual Property, Policy Brief No. 9, April 2011 (ICTSD 2011); Suerie Moon, 'Does TRIPS Art 66.2 Encourage Technology Transfer to LDCs? An Analysis of Country Submission to the TRIPS Council' (UNCTAD-ICTSD 2008); Carlos M Correa, 'Review of the TRIPS Agreement: Fostering the Transfer of Technology to Developing Countries' (1999) 2 The Journal of World Intellectual Property 939-60.

28 Tu Thanh Nguyen, Competition Law, Technology Transfer and the TRIPS Agreement: Implications for Developing Countries (Edward Elgar 2010).

29 Richard A Epstein and F Scott Kieff, 'Questioning the Frequency and Wisdom of Compulsory Licensing for Pharmaceutical Patents' (2010) 78 University of Chicago Law Review 71-94; see also Jerome H Reichman, 'Compulsory Licensing of Patented Pharmaceutical Inventions: Evaluating the Options' (2009) 37 Journal of Law, Medicine and Ethics 247-63.

30 Udo Schuklenk and Richard E Ashcroft, 'Affordable Access to Essential Medication in Developing Countries: Conflicts between Ethical and Economic Imperatives' (2010) 27 Journal of Medicine and Philosophy 179-95. 
by developing countries. ${ }^{31}$ Earlier works have also stressed the need for compulsory licensing as a tool for improving public health in countries with insufficient or no manufacturing capacity in the pharmaceutical sector. $^{32}$

As far as access to technologies is concerned, much emphasis has been put on facilitating access to medicine and pharmaceutical patents. Blaming intellectual property for causing the high prices of patented drugs and thus restricting access to medicine in less developed countries, several scholars have pleaded for the abandonment of pharmaceutical patents, or - at least - imposing a legal requirement on pharmaceutical companies to limit the effects of the exclusive rights granted to patentees and making essential medicines accessible. ${ }^{33}$ Recently, there has also been interest in transferring green technologies to developing countries. The debate around these issues aims at ensuring that IPRs do not restrict the transfer of climate-friendly technologies to developing countries to address key issues such as climate change. To this end, there is a need for developing countries to get access to technologies that facilitate the transition to a less carbon-intensive economy, which may be tackled by combining policy measures with amendments to the international intellectual property regime. ${ }^{34}$ Indeed, it has been recommended that flexibilities in both domestic and international legal frameworks related to the promotion of

31 Rosa Castro, 'Compulsory Licensing and Public Health: TRIPS-Plus Standards in Investment Agreements' (SSRN, 7 July 2012 (written May 2009)) http://papers.ssrn.com/sol3/papers.cfm?abstract_id=2101574, accessed 14 January 2016 .

32 Frederick M Abbott and Rudolf Van Puymbroeck, 'Compulsory Licensing for Public Health: A Guide and Model Documents for Implementation of the Doha Declaration Paragraph 6 Decision' World Bank Working Paper No. 61 (2005).

33 Yahong Li, 'Intellectual Property and Public Health: Two Sides of the Same Coin' (2011) 6 Asian Journal of WTO and International Health 389-427; Tahir Amin, 'Re-Visiting the Patents and Access to Medicines Dichotomy: An Evaluation of TRIPS Implementation and Public Health Safeguards in Developing Countries' in O Aginam, J Harrington and P K Yu (eds), Global Governance of HIV/AIDS: Intellectual Property and Access to Essential Medicines (Edward Elgar 2013); Greg Martin, Corinna Sorenson and Thomas Alured Faunce, 'Balancing Intellectual Monopoly Privileges and the Need for Essential Medicines' (2007) 3 Globalization and Health 4-8.

34 Robert V Percival and Alan Miller, 'Resolving Conflicts between Green Technology Transfer and Intellectual Property' (2011) Climate Change, Sustainable Development, and Ecosystems Committee Newsletter 18; Kim Hee Eun, The Role of the Patent System in Stimulating Innovation and Technology Transfer for Climate Change (Nomos 2011); Krishna Ravi Srinivas, 'Climate Change, 
international technology transfer, are needed to overcome the classic intellectual property paradigm between producers and consumers of technologies. Similarly, striking the appropriate balance in IPRs between the originating and recipient countries is important to facilitate the absorption of new technologies by developing countries to address the climate change issue. ${ }^{35}$ From an economic perspective, authors have investigated the extent to which transferring technologies to developing countries depends on whether the mechanism of transfer is rightly adapted to the absorptive capacity of the economy. They have argued that absorptive capacity can differ depending on the stage of the economy's development. Each stage requires an adequate mechanism of technology transfer. ${ }^{36}$ Other works stress the need for international regulation facilitating the transfer of technologies from the developed to the developing world, particularly by reaching an agreement on codes of conduct for the transfer of technology. ${ }^{37}$

Apart from that, various projects have been deployed by international organisations for the dissemination and transfer of technologies to the developing world. The World Intellectual Property Organization (WIPO) is playing a significant role in this regard, but not only WIPO; other organisations are similarly concerned with the transfer of technologies to the developing world such as the United Nations Conference on Trade and Development (UNCTAD) and the World Health Organization (WHO). ${ }^{38}$

Technology Transfer and Intellectual Property Rights' (2009) Research Information System for Developing Countries, TIS Discussion Paper Series, RIS-DP \#153 2009.

35 Keith E Maskus and Ruth L Okediji, 'Intellectual Property and International Technology Transfer to Address Climate Change: Risks, Opportunities and Policy Options' (ICTSD 2010); Keith E Maskus, 'Differentiated Intellectual Property Regimes for Environmental and Climate Technologies' (2010) OECD Environment Working Papers No. 17; Sangeeta Shashikant, Intellectual Property and Technology Transfer in the Context of Climate Change (Third World Network 2010).

36 See Barbara Hansen, 'Economic Aspects of Technology Transfer to Developing Countries' (1980) 11 International Review of Industrial Property 429-40.

37 Andres L Guadamuz, 'The Future of Technology Transfer in the Global Village' (2000) 3 The Journal of World Intellectual Property 589-602.

38 See UNCTAD, 'Transfer of Technology and Knowledge Sharing for Development Science, Technology and Innovation Issues for Developing Countries' UNCTAD Current Studies on Science, Technology and Innovation (N8, 2014); UNCTAD, 'UNCTAD Series on Technology Transfer and Development. 


\subsection{HOW THIS BOOK INTENDS TO UTILISE PATENT INFORMATION AS A MEANS FOR DEVELOPMENT?}

This book is an attempt to fill the gap in the literature concerning the capacity of developing countries - among other countries - to exploit technologies described in patent specifications for their own economic development. Almost wholly ignored in most assessments of the contribution of the patent system to the transfer of technology, is the availability of detailed technologies contained in patent documents that can be utilised to achieve growth. ${ }^{39}$ As stated earlier, ever since its inception one of the most significant functions of the patent system has been the promotion of the exchange of technological information. ${ }^{40}$ This book is based on the premise that patent information is an inexpensive and

Facilitating Transfer of Technology to Developing Countries: A Survey of Home-Country Measures' (UNCTAD 2012); UNCTAD, 'Development Dimensions of Intellectual Property in Uganda: Transfer of Technology, Access to Medicines and Textbooks. Overview' (UNCTAD 2010); UNCTAD, 'The Role of Intellectual Property Rights in Technology Transfer in the Context of the Convention on Biological Diversity' (UNCTAD 2007); UNCTAD, 'Agreed Recommendations on the International Policy Issues: International Arrangements for Transfer of Technology: Best Practices for Access to and Measures to Encourage Transfer of Technology with a View to Capacity Building in Developing Countries' (29 February 2002) TD/B/COM.2/L.16 (UNCTAD 2002); WHO, Pharmaceutical Production and Related Technology Transfer (WHO 2011); UNCTAD and WHO, Local Production of Pharmaceuticals and Related Technology Transfer in Developing Countries (UNCTAD 2011); WHO, Increasing Access to Vaccines through Technology Transfer and Local Production (WHO 2011); WHO, Increasing Access to Diagnostics through Technology Transfer and Local Production (WHO 2011); WIPO, 'Project on Intellectual Property and Technology Transfer: Common Challenges - Building Solutions: Recommendations 19, 25, 26, 28', Committee on Development and Intellectual Property (CDIP), 6th session, Geneva, 22 to 26 November 2010 (WIPO Doc CDIP/6/4 Rev); see also WTO, 15 Years of the Information Technology Agreement: Trade, Innovation and Global Production Networks (WTO 2012).

39 Blakeney (n 23 above) 81.

40 Blakeney (n 23 above) suggests that the origins of patent specification which have been traced to the seventeenth century in England, arose more for the purpose of defining the precise scope of the grant than for the instruction of the public ... the patent laws of France expressly provided for the instruction of the public and the promoters of the German patent laws stressed the importance to the stimulation of inventive genius of the publication of patent information' (at 84). On the same subject, see also Judith Allen and Charles Oppenheim, 'The 
comprehensive available source of technical information about the state of the art of major technologies' ${ }^{41}$ It assumes that the availability of concrete solutions to technical problems, in a standardised, concise and relatively easily accessible way, is an indirect means of facilitating the transfer of technology to the developing world. This may be attainable primarily through the utilisation of a selected technology that is freely available in the public domain.

In the exposition of this argument, each chapter of this book represents a step forward in testing the adequacy of the disclosure requirement in facilitating access to, and use of, patent information. While the introductory chapter is mainly dedicated to defining the context and the argument developed in the book and describing the main questions related to it, Chapter 2 explores the significance of patent information. Chapter 3 analyses the foundations of a right to patent information. ${ }^{42}$ Chapter 4 is based on the premise that an explicit right to patent information necessitates adequate disclosure requirements. It considers that an appropriate obligation to substantiate the evidence of completion of the invention through the disclosure of patent information enhances the right to patent information. Chapter 5 goes further by arguing that improving the disclosure requirement might not suffice. Enhanced means of accessing and retrieving patent information are needed for an improved utilisation of such information. ${ }^{43}$ Chapter 6 argues that retrieval of relevant technologies within patent documents necessitates use of appropriate methods of exploiting them for development. ${ }^{44}$ Chapter 7 is dedicated to the Tunisian example. It investigates the extent to which its patent law has enlarged or tightened the scope of the public domain. Chapter 8 aims to investigate ways of improving patent information

Overlap of US and Canadian Patent Literature' (1979) 1 World Patent Information 77-80.

41 Blakeney (n 23 above) 85.

42 Madey v Duke University, 307 F.3d 1343 (Fed Cir 2000). See also Katherine J Strandburg, 'What Does the Public Get? Experimental Use and the Patent Bargain' (2004) Wisconsin Law Review 81-156.

43 Ashish Arora, Marco Ceccagnoli and Wesley M Cohen, 'R\&D and the Patent Premium' (2003) National Bureau of Economic Research Working Paper No. 9431, www.nber.org/papers/w9431.pdf, accessed 14 January 2016: 'Patent disclosures appeared to have no measurable impact on information flows from other firms, and therefore no measurable effect on R\&D productivity' (at 17).

44 Selection of the appropriate technology implies that the latter is freely available for use but also that it meets the industrial and developmental needs of the receiving country. These technical aspects will not be covered by the research included in this book. Only the legal aspects will be analysed. 
users' - particularly those in developing countries - capacity to exploit such information for development. Based on the WIPO Development Agenda, Chapter 9 attempts to scrutinise the extent to which this agenda has addressed the legal and technical barriers - analysed in previous chapters - that inhibit the exploitation of patent information. Ultimately, the book attempts to offer a tool-box of policy measures and mechanisms for policymakers to better utilise patent information for development through incremental innovation. 